\title{
Factors affecting the employability of private university graduates: an exploratory study on Bangladeshi employers
}

\author{
Md Sajjad Hosain \\ Business School, Sichuan University, Chengdu, China \\ Mohitul Ameen Ahmed Mustafi \\ Business School, Uttara University, Dhaka, Bangladesh, and \\ Tania Parvin \\ Department of Finance, Bangladesh University of Professionals, \\ Dhaka, Bangladesh
}

\begin{abstract}
Purpose - This paper aims to identify the factors that can affect the overall graduate employability (OGE) of the private university graduates of Bangladesh. The authors carefully selected six such employable factors after searching the existing literature. Those six factors: academic performance (AP), technical skills (TS), communication skills (CS), personality (PE), leadership \& motivational skills (LMS); and teamwork and problem solving skills (TPSS), had been considered as the independent variables while OGE had been considered as the single dependent variable.

Design/methodology/approach - The authors collected the primary data from a valid sample of 360 employers through a structured questionnaire working as the hiring managers. Those respondents were selected on a random basis. The authors used exploratory factor analysis to validate the items under those independent variables and structural equation modeling with AMOS (24) to test the hypothesized relationship between each independent variable and the dependent one.

Findings - After proper statistical analysis, the results revealed that AP, PE, CS and TPSS can positively and significantly influence the OGE of Bangladeshi graduates while LMS and TS have positive but insignificant influence over OGE.

Research limitations/implications - Based on the findings, this paper can help scholars in further investigating the employability factors.

Practical implications - This explorative study will guide the fresh graduates in developing their required employability skills while assisting the employers in recruiting suitable candidates with the required skills and performance.
\end{abstract}

(C) Md Sajjad Hosain, Mohitul Ameen Ahmed Mustafi and Tania Parvin. Published in PSU Research Review. Published by Emerald Publishing Limited. This article is published under the Creative Commons Attribution (CC BY 4.0) licence. Anyone may reproduce, distribute, translate and create derivative works of this article (for both commercial and non-commercial purposes), subject to full attribution to the original publication and authors. The full terms of this licence maybe seen at http:// creativecommons.org/licences/by/4.0/legalcode

Conflict of interests: The authors declare no conflict of interests.

Source of funding: There is no source of funding to be reported.

Received 12 January 2021 
Originality/value - This is one of the few attempts that focused on the employability factors of private university graduates in Bangladesh. The authors are well confident that this empirical paper can shed some light on the fresh graduates' employability and conducting further investigations on it.

Keywords Employability, Skills, Graduate students, Private universities, Bangladesh

Paper type Research paper

\section{Introduction}

One of the pre-conditions of higher education is to produce entrepreneurs and employable graduates who can serve their respective organizations, society and the country in general through their dedication and innovative skills. As we cannot expect all the graduates to be independent entrepreneurs, we can well assume that majority of the graduates in a country will search for suitable entry-level jobs according to their knowledge, skills and previous performance. The employment rate of graduates is frequently considered as a performance indicator to determine the value of higher education by the governments and international rankings (Teichler, 2009). The prospective students also pay attention to the employment prospects while selecting a university to pursue their higher study. Considering the increasing cost of higher education such as tuition fees and other charges, the national and global competition for attracting students is becoming more rigorous.

Due to the long-term effect of the global recession that began in 2008; and the very recent pandemic situation, the world economy is becoming shrinking substantially. One of the ultimate consequences of such a shrinking world economy is the less purchasing power of general people leading to less production and finally, less employment generation. Therefore, graduate employability has been and will continue to be the talk of the forum for the upcoming period. As a result of many changing circumstances, many countries will observe fewer jobs rather than new graduates at least for the next few years until the national economies will gain their regular speed. Universities and the graduates themselves are required to adopt newer sets of skills and techniques along with the traditional ones to get their expected jobs. In such a time, there is a fundamental and mounting requirement for conducting some empirical studies to investigate the skill sets that the employers are looking for.

There are quite a lot of theoretical and empirical research studies that have enriched academia (Rad et al., 2020; Jayasingha and Suraweera, 2020; Chowdhury, 2019; Chen, 2017; Nazron et al., 2017; Fitriyanto and Pardjono, 2017; Yulia and Yuzhuo, 2017; Gowsalya and Kumar, 2015; Sumanasiri et al., 2015; Ahmed and Crossman, 2014; Dotong, 2014; Shah and Srivastava, 2014; Cai, 2013; Weligamage, 2009; Chisty et al., 2007). However, despite a large number of studies, graduate employability appears to be suffering from the problems of lack of theoretical control. Furthermore, the concept of graduate employability is changing rapidly due to the external natural, political and economic circumstances such as recession, war and very recently, the outbreak of COVID-19. Therefore, the authors believe that there is still a need for further investigations on this specific and vital area of business and economics.

This particular exploratory study was conducted to identify the required factors for the employability of Bangladeshi private university graduates. The authors pre-selected six employable factors after searching the existing literature and made an extensive exploratory factor analysis. Following this step, the authors tried to correlate those factors with the overall graduate employability (OGE). The authors took the perceptions of Bangladeshi employers from a cross-section of industries to make the results more justifiable to the 
readers and scholars. The research question of this exploratory study was been identified as below:

$R Q$. What are the factors that can affect OGE in Bangladesh?

Graduate employability factors

\section{Literature review}

\subsection{Graduate employability}

Graduate employability can generally be defined as the compilation of a series of skills and abilities that a graduate can obtain to achieve a desirable job and succeed in his/her career (Chen, 2017; Tomlinson, 2012). Such skills and capabilities enable the graduate job candidates to meet the desired requirements of employers and adapt to changes in the labor market. It is a type of all-inclusive set of skills and abilities to improve future career development. Based on the existing published research works that primarily started from the 1990s, can be separated into two categories. The first one is from the standpoint of employment performance which proposes that employability is a combination of multifaced dimensions, including interior and exterior factors (Guilbert et al., 2016). The internal factors include personal knowledge and skills associated with the job such as technical and team working skills, while the external factors include the condition of the labor market such as labor demand and supply (Tholen, 2014).

The second set of skills and capabilities can be viewed from the standpoint of personal ability that considers the graduate employability is the outcome of individual ability and is a collection of competitive skills and abilities that help the graduates to attain employment and develop (Tholen, 2014). Therefore, graduate employability is a complete set of skills to improve graduates to further career development (Finch et al., 2013). Such a set includes a series of skills, knowledge and personality traits (Yorke and Knight, 2007). As a sort of personal ability, the composition of graduate employability includes basic personal and social attributes, leadership skills, communication skills (CS) and teamwork skills (McQuaid and Lindsay, 2005). However, the existing most researched studies emphasized that graduate employability is a sort of "soft skills" to acquire jobs and getting career success (Chen, 2017; Reid, 2016; Kalfa and Taksa, 2015).

Previous research studies have identified a number of numbers of factors that can affect graduate employability. A study conducted by Weligamage and Siengthai (2003) on "employer needs and graduate skills" establishes seven vital expected factors that employers consider when recruiting fresh graduates are CS, general knowledge, personality (PE), computer and IT skills, verbal CS, realistic experience and educational background. According to Paddi (2014), most sought-after graduates should be proficient in teamwork, communication, analytic \& critical thinking and IT skill. As pointed by Liyanage et al. (2016), graduates' realistic knowledge, logical ability, dedication to work, communication \& IT skills, management skills and positive attitudes are the highly concerned factors among employers. Another study conducted by Ambepitiya (2016) at two management education institutes in Sri Lanka observed that academic knowledge, soft, practical and technical skill development are the major factors that prepare a graduate ready for employment. Those results also concluded that although academic knowledge is an important factor, it is not the sole one for the effective employability of graduates (Jayasingha and Suraweera, 2020). However, this study considered six pre-selected factors for graduate employability in the Bangladeshi job scenario. Those six factors are academic performance (AP), technical skills (TS), communication skills (CS), personality (PE), leadership \& motivational skills (LMS); and teamwork \& problem solving skills (TPSS). 
Academic performance (AP) is generally indicated through grade point average (GPA) or cumulative grade point average (CGPA) measured by various academic indicators such as class performance, assignments, presentation skills; and exam results. Numerous scholars identified a positive association between AP and OGE. Pinto and Ramalheira (2017) examined whether the AP and the participation in extra-curricular activities (ECA) affect the perceived employability of business graduates using an experimental study between-subjects factorial design on 349 Portuguese working adults. They found that AP published through GPA is the key to lift up business graduates' employability. GPA and ECAs jointly foster business graduates' employability. Almost similar findings were reported by Helena and Kena (2019) where they argued that AP along with participation in ECA results in higher rates of job suitability and employability skills for Chinese graduates. Fenta et al. (2019) also identified that graduates' initial employability has a positive relationship with CGPA, preferred field of study and internship practice.

On the contrary, Soon et al. (2019) pointed that AP is not a key determinant in whether or not a graduate secures a job upon graduation and that having a better AP would only be beneficial if the graduates are working in jobs at the lower half of the salary distribution. Therefore, there are contrasting views regarding the influence of AP on OGE. However, this study included AP as one of the indicators of OGE for Bangladeshi graduates:

H1. AP can positively and significantly affect OGE for Bangladeshi graduates.

\subsection{Technical skill and overall graduate employability}

Technical skill (TS) refers to the skills related to learning and acquiring different tools and techniques such as software, computer and IT. In a present competitive world, such a set of skills are quite essential due to the rapid changes in adopting IT and Internet. Furthermore, an employee is expected to be competent in using different software although those competencies vary according to the nature of the jobs. Mansour and Dean (2016) argue that employers require employees to have both TS. as well as soft or non-TS. Another recent study conducted in Sri Lanka by Jayasingha and Suraweera (2020) found that TS such as IT skills can partially influence OGE and have not reflected a significant impact on OGE. In a very recent study carried out in Bangladesh, Hossain et al. (2020) identified that both soft skills and TS are positively related to employability, which is consistent with prior studies. They suggested creating more technically skilled graduates particularly in a Bangladeshi job market where labor supply is abundant but skilled candidates are scarce.

On the other hand, Nazron et al. (2017) revealed that the attributes such as ICT and TS have no significant association with OGE. However, this study considered TS as one of the factors required for being employable:

H2. TS can positively and significantly affect OGE for Bangladeshi graduates.

\subsection{Personality and overall graduate employability}

Personality (PE) indicates a distinctive manner of thinking, feeling and behaving. It embraces moods, attitudes and opinions; and is expressed while interactions with other people. It includes behavioral uniqueness, both inherent and acquired, that distinguishes one person from another and that can be observed through a person's relationships to the environment and the social groups. Potgieter and Coetzee (2013) investigated the employability attributes and PE preferences of postgraduate business management 
students in South Africa and found significant relationships between the participants' PE preferences and their employability attributes. Qureshi et al. (2016) identified PE as a predictor of engagement and employability. Neneh (2019) conducted an empirical study on PE traits, job market appraisal and self-perceived employability in an uncertain market and ultimately revealed that agreeableness, conscientiousness and openness to experience are positively and significantly associated with self-perceived employability. Based on the literature, this study included PE as one of the factors influencing graduate employability:

H3. PE can positively and significantly affect OGE for Bangladeshi graduates.

\subsection{Communication skill and overall graduate employability}

Commutation skill (CS) generally refers to the ability to communicate with others effectively through sending and receiving the intended meaning. It can be done face to face, online or by mail. Effective communication and interaction reduce the perception bias, time and effort to enhance further efficiency. Rasul et al. (2013) investigated the graduate employability factors for the manufacturing industry and identified that employers place great importance on CS, problem-solving skills, teamwork skills and personal qualities. They argued that the graduates also need to emphasize leadership skills, entrepreneur skills, technology skills and informational skills. Another study conducted by Shah and Srivastava (2014) on the factors affecting the employability skills of management students and revealed that four factors: analytical skills \& self-understanding, general management \& work culture, leadership \& problem-solving ability and communication make a significant impact on employability skills of management graduates. A recent study conducted by Succi and Canovi (2020) in different European countries identified that soft skills including communication skills, interpersonal skills and problem-solving skills increase the likelihood of employability of the students/graduates.

However, a complete opposite view was expressed by Nazron et al. (2017), who investigated the relationship between graduate's soft skill attributes and employment status among students in University Malaysia Sabah (UMS). They found that the attributes examined (knowledge, ICT skills, TS, problem-solving, CS, teamwork, leadership, professionalism and ethics) have no significant relationship with the employment status of the graduates. Despite the opposing views, the authors included CS as one of the factors that can positively affect OGE for Bangladeshi graduates:

H4. CS can positively and significantly affect OGE for Bangladeshi graduates.

\subsection{Leadership \& motivational skills and overall graduate employability}

Leadership skills refer to effectively lead a team or subordinate(s) whereas motivational skills refer to motivate and positively influence a team or working partners. A good leader is always supposed to motivate and guide his/her followers or subordinates in a constructive manner. Rasul et al. (2013) investigated the graduate employability factors for the manufacturing industry and recognized that the graduates need to emphasize leadership \& motivational skill (LMS) along with other qualities. Rahman et al. (2016) identified that low motivational level, lack of creativity and leadership values are among the major weaknesses of the graduate students in getting employed. Subbu and Rajasekaran (2018) made an extensive literature survey on the employability skills in the Indian job market and commented that LMS has a widening impact on OGE:

H5. LMS can positively and significantly affect OGE for Bangladeshi graduates. 
Team working indicates an interpersonal skill of a person who can effectively communicate with a team and can accomplish his/her role as a part of the team. On the other hand, problem-solving skill refers to effectively solving a practical or simulated problem in an efficient manner. Teamwork and problem solving skills (TPSS) are the two vital skills that make a job candidate competent in any situation. Numerous studies confirmed that these two skills are imperative for a graduate in getting an expected job. Gowsalya and Kumar (2015) identified that TPSS can highly increase the chance of a graduate being employed. Nazron et al. (2017) supported such findings and found that TPSS can raise the employment status among the students in University Malaysia Sabah (UMS). Nusrat and Sultana (2019) investigated the impact of soft skills on sustainable employment of business graduates in Bangladesh and reported that soft skills including TPSS can, in fact, not only assist in getting a job but also sustain it for longer. These two combined skills together were considered as one of the independent factors of employability in this explorative study:

H6. TPSS can positively and significantly affect OGE for Bangladeshi graduates.

\subsection{Theoretical model}

This explorative study involves six independent variables with one single dependent variable: OGE. The theoretical model has been illustrated in the following diagram (Figure 1):

\section{Research method}

\subsection{Collection of data}

Primary data were collected for this explorative study as the secondary information are not suitable for the quantitative scale measurement. A detailed structured survey questionnaire was used to collect data from the respondents who had been chosen using a random sampling method from the two big cities (Dhaka and Chattogram) of Bangladesh.

Figure 1.

Theoretical model (all the relationships were hypothesized to be positive)

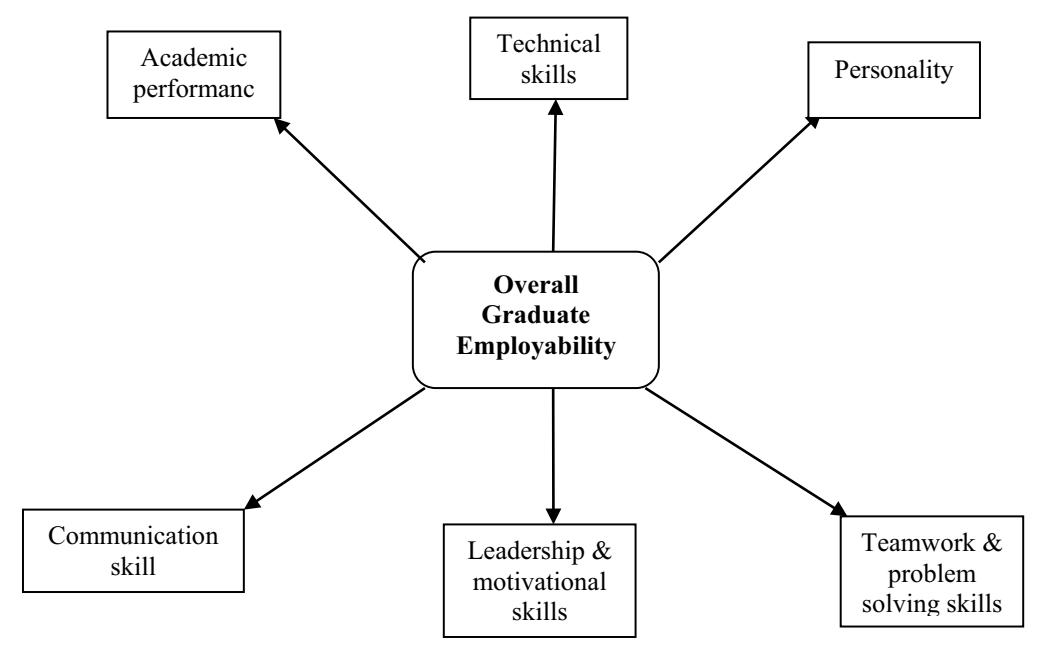

Source: Authors' elaboration 
Initially, 400 questionnaires were distributed to the employers and HR professionals working as the recruitment and selection officers at 11 job sectors in Bangladesh. Afterward, the authors received 370 questionnaires (with a response rate of 92.5\%) where 10 questionnaires were found incomplete, biased and/or abnormally answered, and hence discarded through scrutinizing process. Finally, the valid data (n) used for this study was 360. The analysis was made by using multivariate analysis techniques such as exploratory factor analysis, confirmatory factor analysis and structural equation modeling.

\subsection{Determination of sample size}

As a medium-sized economy, the Bangladeshi job sector is not large enough to feed its entire unemployed people. To determine the sample size of the employers, the formula published by the University of Florida was used as a reference. This study used a formula for taking sample data from population suggested by Yamane (1967):

$$
\mathrm{n}=\frac{N}{\left(1+N e^{2}\right)}
$$

where $n$ = sample size, $\mathrm{N}=$ population, e = level of precision. In calculating a number of samples, the following assumptions were made to determine: $n=330$, if population size is 400,000 ; level of precision is $5 \%$. However, 360 respondents had been taken as valid in this study.

\subsection{Survey instrument}

This study selected 360 recruiting officers working at 11 different job sectors in Bangladesh. A structured questionnaire with 23 items was used to collect the data developed by literature review. This structured questionnaire with a five-point Likert scale was used for collecting the pertinent data from the respondents. Table 1 highlights the number of items for each independent variable and the dependent one.

\subsection{Validity and reliability of the items included on the survey instrument}

If numerous items are used to determine an individual construct, the items' (indicator) convergent validity should be one of the main concerns to the researcher that can be explained as the degree to which multiple items to measure the identical concept are in concord (Hair et al., 2010). According to Hair et al. (1998), convergent validity could be accessed through composite reliability (CR). The results of the measurement model (Table 2)

Variables

Overall graduate employability (dependent)

Academic performance (independent)

Technical skill (independent)

Personality (independent)

Communication skill (independent)

Leadership and motivational skills (independent)

Teamwork and problem-solving skills (independent)

Total number of items

Source: Survey instrument
Graduate employability factors

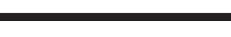


indicate that the factor loadings for all items surpassed the recommended value of 0.70 (MacKinnon, 2008). The CR values ranged from 0.72 to 0.93 which exceeded the recommended value of 0.70 .

On the other hand, to analyze the reliability (internal consistency) of the variables, this study used the Cronbach's alpha coefficient and $\mathrm{CR}$ value. Table 2 shows that all the Cronbach's alpha values are above 0.60 cutoff values as suggested by Nunnally and Bernstein (1994). Therefore, the results of reliability and validity indicate that each individual item is internally consistent and has a fairly high degree of reliability.

\section{Analysis and interpretation}

\subsection{Demographic characteristics}

Table 3 highlights the demographic characteristics of the participants of this study. It indicates that more than three-fourths of the participants are male while the majority of them are between the age range of 35 to 44 years. Most of the respondents are Master degree holders while there are a handful of $\mathrm{PhD}$ degree holders as well. Regarding the length of

Table 2.

Reliability and validity of the questionnaire items

\begin{tabular}{llllllll}
\hline Factors & EM & LMS & TS & TPS & PE & AP & CS \\
\hline EM & 0.93 & & & & & & \\
LMS & 0.06 & 0.81 & & & & & \\
TS & $0.303^{* * *}$ & $0.457^{* * *}$ & 0.83 & & & & \\
TPS & $0.547^{* * *}$ & $0.112 \dagger$ & $0.472^{* * * *}$ & 0.90 & & & \\
PE & $-0.099 \dagger$ & $0.462^{* * *}$ & $0.221^{* * *}$ & 0.07 & 0.79 & & \\
AP & -0.08 & $0.160^{*}$ & $0.199^{* *}$ & 0.08 & 0.05 & 0.73 & \\
CS & $0.359^{* * *}$ & -0.02 & $0.369^{* * *}$ & $0.313^{* * *}$ & -0.10 & -0.03 & 0.72
\end{tabular}

Note: Significance of correlations: $\dagger p<0.100, * p<0.050$, *** $p<0.010 * * * p<0.001$

Source: Descriptive statistics (SPSS 24)

\begin{tabular}{|c|c|c|c|}
\hline Demographic variables & Category & Arithmetic no. & $(\%)$ \\
\hline \multirow[t]{3}{*}{ Gender } & Male & 277 & 76.94 \\
\hline & Female & 83 & 23.06 \\
\hline & Total $(n)$ & 360 & 100 \\
\hline \multirow[t]{4}{*}{ Age range (in year) } & $25-34$ & 95 & 26.39 \\
\hline & $35-44$ & 211 & 58.61 \\
\hline & 45 or more & 54 & 15 \\
\hline & Total $(n)$ & 360 & 100 \\
\hline \multirow[t]{4}{*}{ Educational level } & Undergraduate & 48 & 13.33 \\
\hline & Master & 301 & 83.61 \\
\hline & $\mathrm{PhD}$ & 11 & 3,06 \\
\hline & Total $(n)$ & 360 & 100 \\
\hline \multirow[t]{5}{*}{ Length of service (in years) } & 5 or less & 35 & 9.72 \\
\hline & $6-10$ & 112 & 31.11 \\
\hline & $11-15$ & 123 & 34.17 \\
\hline & 16 or more & 90 & 25 \\
\hline & Total $(n)$ & 360 & 100 \\
\hline
\end{tabular}

Table 3.

Demographic characteristics of the participants

Source: Demographic components of the questionnaire 
service, more than one-third of them $(34.17 \%)$ have experienced between 11 and 15 years followed by a segment of 6 to 10 years $(31.11 \%)$ ). Exactly one-fourth of the participants have job experience of 16 years or more.

Graduate employability factors

\subsection{Normality of data}

Fairly normal distribution for the indicators of the latent factors in terms of skewness was observed (Table 4). However, a mild kurtosis for the indicators of the independent variable (LMS2) was evident although the highest kurtosis value is well below 2.6. While such value does violate strict rules of normality, it is still within the more relaxed rules suggested by Sposito et al. (1983), who recommend 3.3 as the upper threshold for normality.

\subsection{Exploratory factor analysis}

To assess EFA, four commonly used assumptions were followed (Hair et al., 1998; Field, 2000) such as sampling adequacy (Kaisers-Mayesolkin) measure greater than 0.5; the minimum eigenvalue for each factor; considering the sample size, factor loading of 0.50 for each item was considered as the threshold for retaining items to ensure greater confidence and varimax rotation was used, as it is a good general approach that simplifies the interpretations of the factors (Field, 2000).

Table 5 shows the EFA results. Hair et al. (2010) suggested that factor analysis can be performed when the Kaiser-Meyer-Olkin (KMO) test and Bartlett's test of sphericity are significant. An index of Kaiser's measures of sampling adequacy (overall MSA = 0.838) and Bartlett's test of sphericity $x^{2}(p=0.000)$ suggested that the factor analysis is appropriate for further analyzing the data for this study. After examining the pattern matrix of EFA, this study found that all the items had factor loadings greater than 0.50 (Table 5).

The first factor (OGE) can explain $24.54 \%$ of the total variance with three items, the second factor (LMS) can explain $16.65 \%$ of the total variance with four items, the third factor (TS) can explain $7.56 \%$ of the total variance with three items, the fourth factor (TPSS) can explain $7.02 \%$ of the total variance with three items, the fifth factor (PE) can explain $6.06 \%$ of the total variance with four items, the sixth factor (AP) can explain $5.59 \%$ of the total variance with three items and the last factor (CS) can explain $3.78 \%$ of the total variance with three items in this analysis. Also, the reliability values (Cronbach's Alpha) of all factors are greater than 0.7 satisfying the threshold value as recommended by Nunnally and Bernstein (1994). Finally, all 23 items were found to be suitable for further analysis such as confirmatory factor analysis and structural equation modeling.

The results indicate that the factor analysis is appropriate. After confirming research constructs, maximum likelihood (ML) and the Promax method (PM) were specifically used to extract factors from 23 items. Hair et al. (2010) recommended that each item factor loading must be more than 0.40 values to be considered as highly significant. Based on an eigenvalue greater than 1, a six-factor model was identified that explains $71.72 \%$ of the total variance of the data set. As a whole, 23 items were grouped (based on eigenvalue) into seven different factors. The EFA result also showed 0.55 as the lowest and 0.981 as the highest factor loadings of the variables. The result of the factor analysis showed that all the factors, as a whole, are acceptable for further analysis (Table 5).

\subsection{Confirmatory factor analysis}

Confirmatory factor analysis (CFA) is a statistical technique used to verify the factor structure of a set of observed variables. CFA allows the researchers to confirm that the variables are related to the respective factor. The relative Chi-Square for this model was 3.097 that is smaller than 5.0 as recommended by Marsh and Hocevar (1985) while other fit 
PRR

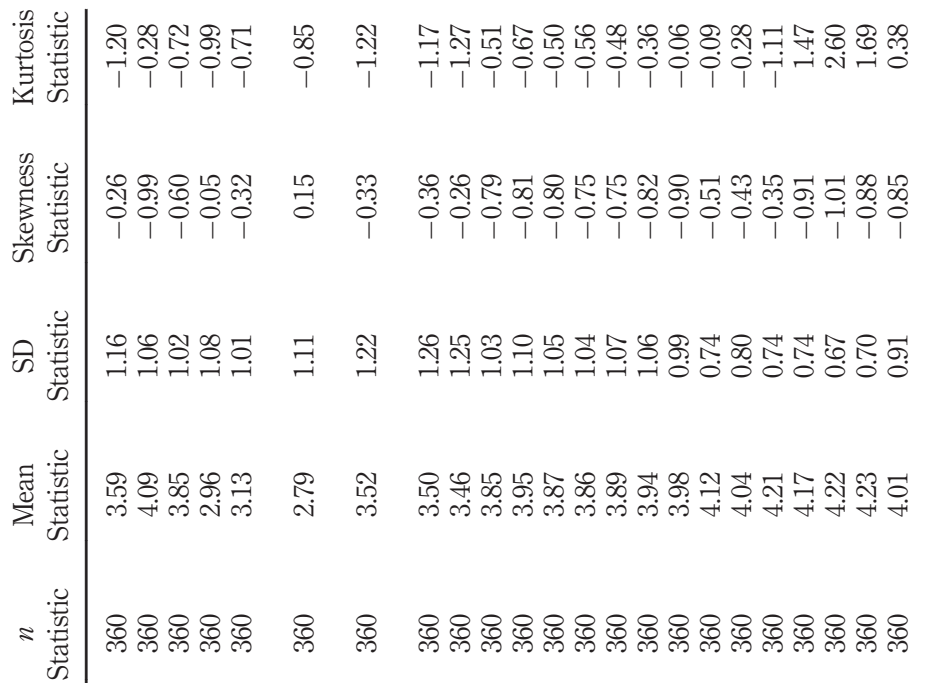

Table 4.

Normality of the data

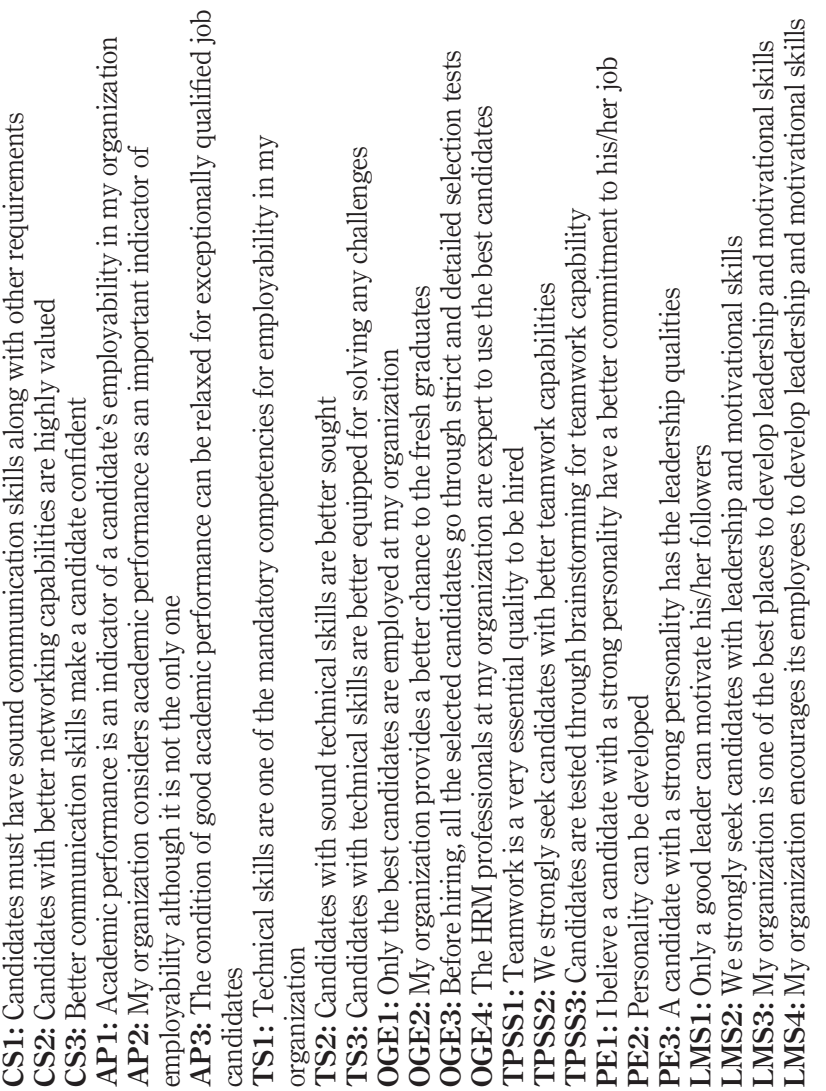




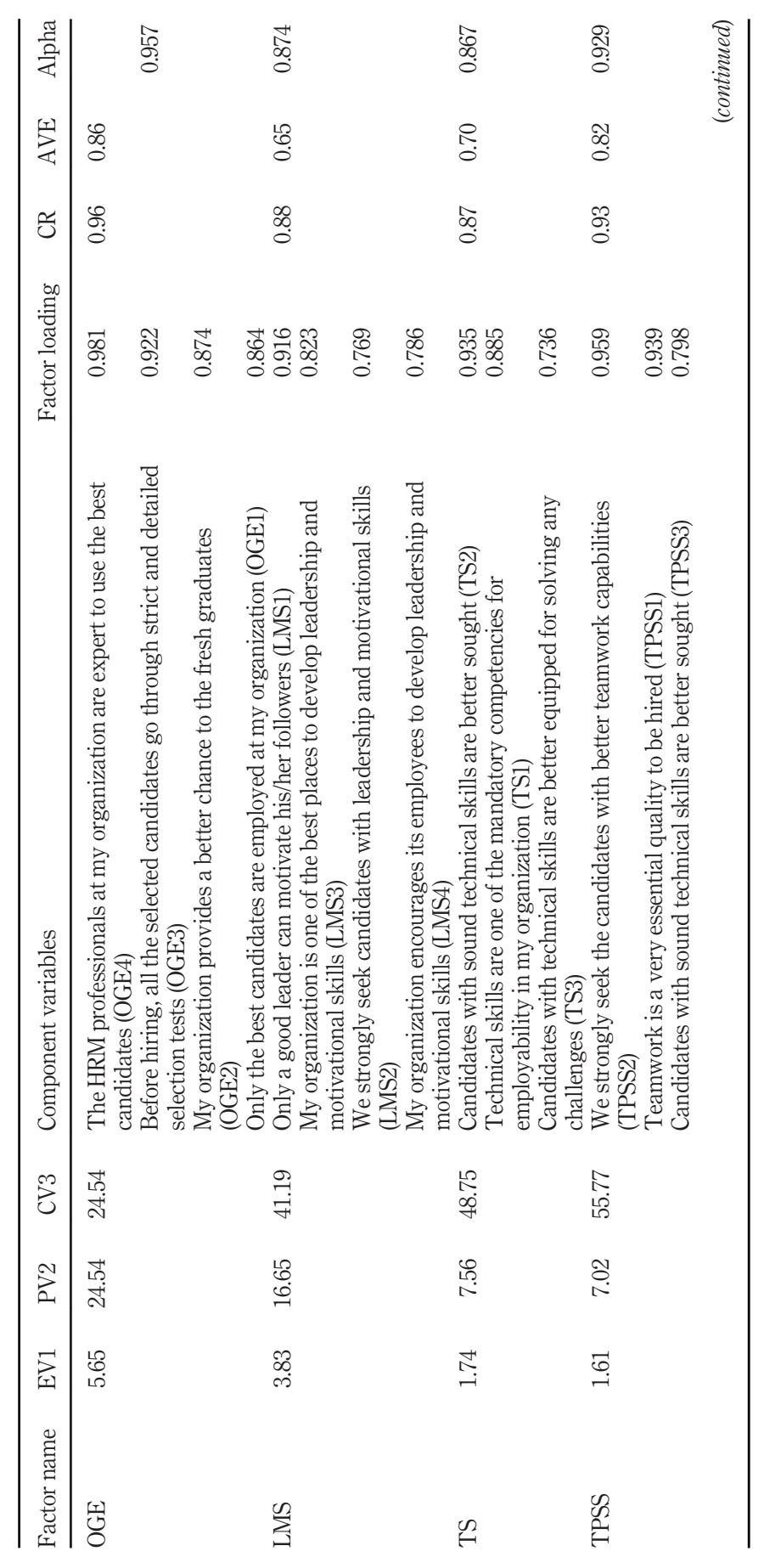

Graduate employability factors

Table 5. Exploratory factor analysis 
PRR

Table 5.

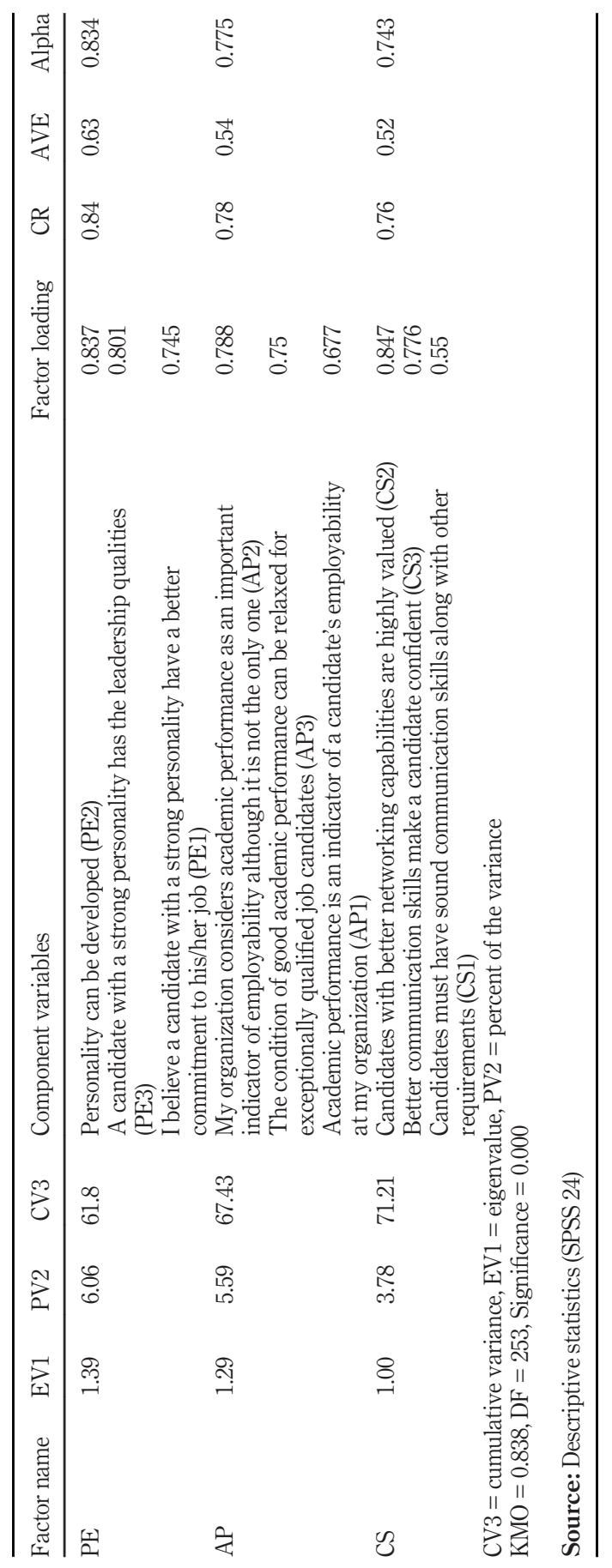


indexes also showed a good fit for the measurement model. The GFI of the model is 0.903 which is more than the recommended value of 0.90 suggested by Joreskog and Sorbom (1993). The summary result of the analysis is shown in Figure 2 and Table 6 . The fit indices showed a good model fit to the data.

In the present study, the adjusted goodness of fit index (AGFI) was found to be 0.861 which meets the recommended value of $(>0.85)$, hence deemed to be a good fit and acceptable supported by Anderson and Gerbing (1984). Furthermore, the non-incremental fit index such as the comparative fit index (CFI) is 0.918 that exceeds the recommended cut-off level of 0.90 (Bentler, 1990). In the CFA, the root mean residual (RMR) value was found to be 0.077, which is less than 0.08 and is commonly recommended as acceptable (Hu and Bentler, 1998). The root mean square error of approximation (RMSEA) is 0.079 , which is also less than the suggested good fit to the data (Browne and Cudeck, 1993). Finally, the standardized means square residual (SRMR) is 0.079 which is less than 0.08 recommend by Browne and Cudeck (1993).

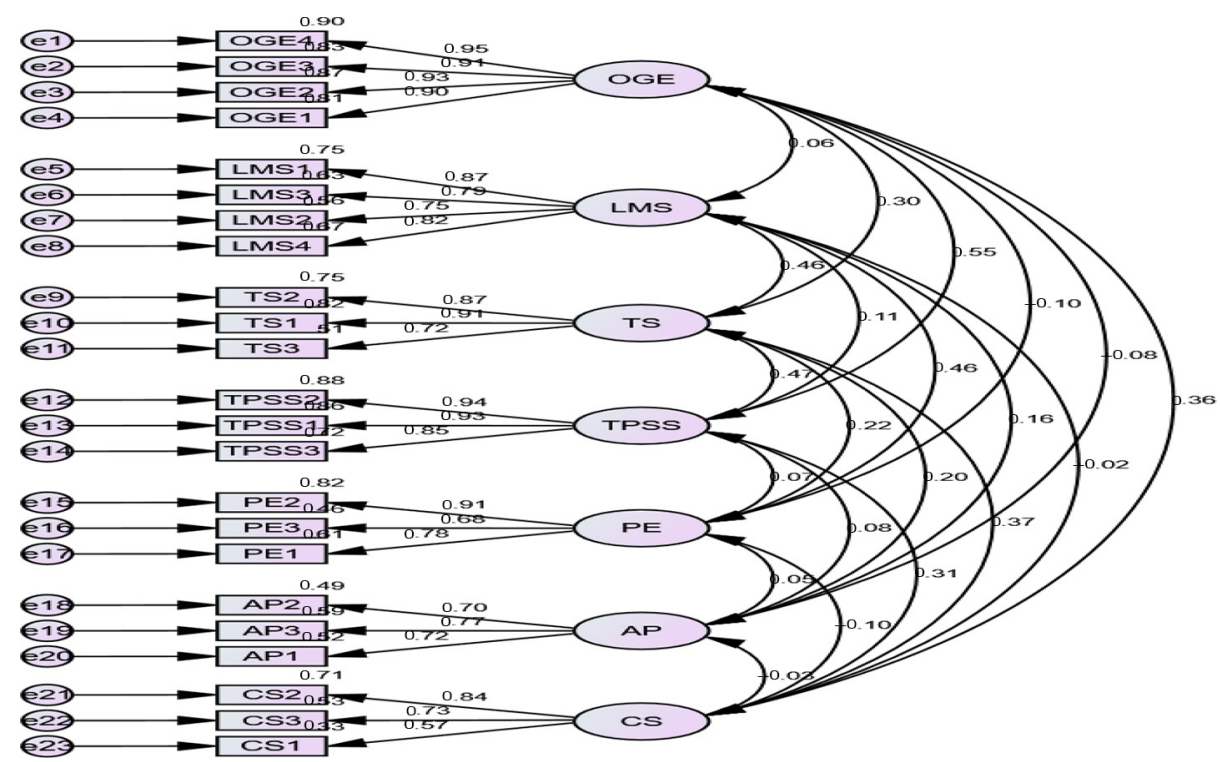

Figure 2.

Confirmatory factor analysisSource:

Structural equation modeling (AMOS 24)

\begin{tabular}{lccl}
\hline Goodness of fit indices & Value & Level of acceptance & Reference \\
\hline Chi-square/df & 3.097 & $<5.0$ & Marsh and Hocevar (1985) \\
CFI & 0.918 & $>0.90$ & Bentler (1990) \\
RMR & 0.077 & $<0.08$ & Hu and Bentler (1998) \\
GFI & 0.903 & $>0.90$ & Joreskog and Sorbom (1993) \\
AGFI & 0.861 & $>0.85$ & Anderson and Gerbing (1984) \\
RMSEA & 0.079 & $<0.08$ & Browne and Cudeck (1993) \\
SRMR & 0.079 & $<0.08$ &
\end{tabular}

Source: Literature review

Table 6.

Model fit indices and their acceptable thresholds 
Variance inflation factors (VIFs) range from 1 to 10 and upwards. The VIF numerical tells us what percentage of the variance is inflated for each coefficient. A rule of thumb for interpreting the variance inflation factor, 1 represents not correlated, between 1 and 5 are moderately correlated and greater than 5 represents highly correlation.

To check the influence of multicollinearity, the VIFs were calculated and found to be with a maximum value of 2.2 as shown in Table 7 which is at a permissible limit as recommended by Hair et al. (1998).

\subsection{Common method bias test}

A Harman's single factor test can be used if the majority of the variance can be explained by a single factor. If a single factor will not explain the majority of variance, it can be assumed that the common method bias (CMB) has not occurred.

According to the results indicated in Table 8, a single factor can explain only $21.548 \%$ variance of this study that means that $\mathrm{CMB}$ did not occur in this study.

\subsection{Structural equation model}

A multivariate analysis technique (covariance-based structural equation modeling) was utilized to identify the significant relationships among six different employability factors. The overall factor concerning the employability of the private university graduates of Bangladesh and the six factors identified through factor analysis have been listed in Table 9 with the structural parameter estimates and hypothesis testing results.

The path diagram of this study revealed that four factors: AP, PE, TPSS and CS together can significantly explain $37.2 \%$ of employability of Bangladeshi private university graduates (Table 9) supporting the hypotheses $H 1, H 3, H 4$ and $H 6$. On the other hand, two factors: LMS and TS have a positive but insignificant influence over the single dependent variable OGE. Therefore, hypotheses $H 2$ and $H 5$ had been rejected. The structural equation model has been shown in Table 9 and Figure 3 .

\section{Discussion of results}

The results of this exploratory investigation point that all of the six selected factors have positive effects on the OGE of Bangladeshi private university students. However, four of them (AP, PE, CS, TPSS) can strongly influence the overall employability supporting the

Table 7.

Variance inflation Tolerance VIF

0.716

1.398

0.922

1.084

0.721

1.387

\subsection{3}

1.422

Source: Structural equation modeling (AMOS 24)

Table 8.

Common method bias test

\begin{tabular}{|c|c|c|c|c|c|c|}
\hline \multirow[b]{3}{*}{ Component } & \multicolumn{6}{|c|}{ Total variance explained } \\
\hline & & Initial eigen & alues & & action sums of sc & ared loadings \\
\hline & Total & $\%$ of variance & Cumulative (\%) & Total & $\%$ of variance & Cumulative $(\%)$ \\
\hline 1 & 6.212 & 27.009 & 27.009 & 4.956 & 21.548 & 21.548 \\
\hline
\end{tabular}


major previous findings of Succi and Canovi (2020), Fenta et al. (2019), Helena and Kena (2019), Neneh (2019), Nusrat and Sultana (2019), Qureshi et al. (2019), Pinto and Ramalheira (2017), Nazron et al. (2017), Shah and Srivastava (2014), Rasul et al. (2013), Gowsalya and Kumar (2015) and Potgieter and Coetzee (2013).

On the other hand, according to the analysis, LMS and TS can inadequately influence graduate employability. Such results largely oppose the previous findings while having a limited consistency with the findings of Nazron et al. (2017). As the job market perspective is different in different countries, such results are not very unusual. However, although the last two mentioned factors cannot adequately influence the OGE, they are still essential as two important skills that can enhance the chance of getting expected jobs.

\section{Theoretical and practical implications}

Employability has been always a center of attraction to the university management,

researchers, economists and obviously the graduates themselves. This research is expected

\begin{tabular}{llccccl}
\hline Relationship & Hypothesis & Estimate & S.E. & C.R. & $p$ & Label \\
\hline OGE $\leftarrow$ AP & $H 1$ & 0.173 & 0.075 & 2.292 & 0.022 & Supported \\
OGE $\leftarrow$ TS & $H 2$ & 0.020 & 0.064 & 0.308 & 0.758 & Not supported \\
EM $\leftarrow$ PE & $H 3$ & 0.215 & 0.079 & 2.736 & 0.006 & Supported \\
EM $\leftarrow$ CS & $H 4$ & 0.199 & 0.067 & 2.956 & 0.003 & Supported \\
EM $\leftarrow$ LMS & H5 & 0.144 & 0.101 & 1.430 & 0.153 & Not supported \\
EM $\leftarrow$ TPSS & $H 6$ & 0.486 & 0.057 & 8.530 & $* * *$ & Supported \\
OGE & & & & 0.372 & &
\end{tabular}

Note: $* * *$ indicates $p$ value $<0.001$

Graduate employability factors

Regression weights: (group number 1 default model)

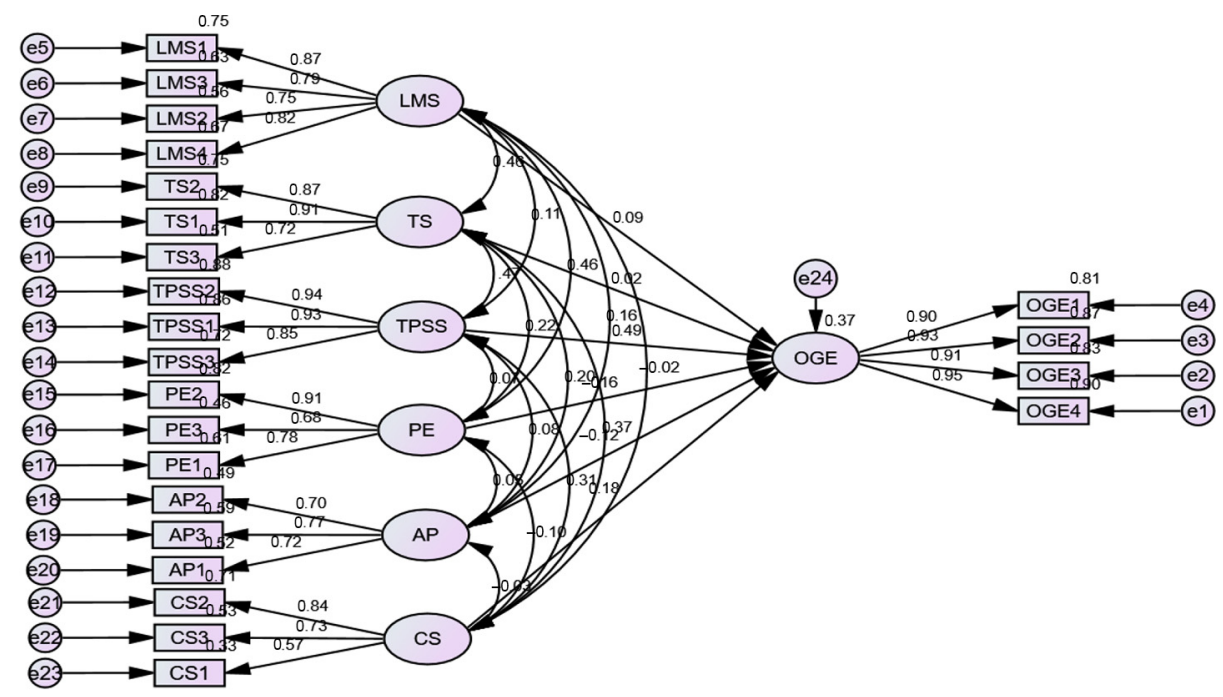

Figure 3. Path model

Source: Structural equation modeling (AMOS 24) estimation 
to contribute to the understanding of employability skills that can affect the OGE in Bangladeshi work settings. As an important research priority for any country, more and more empirical investigations are required to be conducted in this area. The authors expect that this empirical study can enrich such effort to a further extent.

On the other hand, these empirical findings will drop some guided results for the new graduates allowing them to amplify in boosting their skill set. Moreover, the employers can also get some clues from the studies like this one.

\section{Limitations and further scope}

The study has several limitations that need to be pointed out. First of all, the study was limited to only the private university graduates of Bangladesh. Second, the scope of this study was limited to only a few skills based on one particular country. A cross-cultural study or comparative analysis taking more factors might have provided different and wider conclusions.

Therefore, there is a gap that could be bridged and an opportunity to conduct further analysis on this important area of management. The authors are expecting that more and more empirical investigations will be conducted in the future considering the above limitations and overcoming them.

\section{Conclusion}

Although within the present optimistic economy, a growing number of development projects and rapid industrialization are expected to create the necessary levels of employment for the university graduates, it cannot guarantee a perfect match between graduate qualities and employer needs. Therefore, establishing the relationship between the two would necessitate indepth research studies. The perspectives of all the stakeholders such as graduates, employers and tertiary education providers need to be sought after to offer a holistic view of multifaceted employability factors. Conducting enquiries along these lines might shed some light on perceptions of the quality of the various programs that the private universities offer. The quick rise of private universities in Bangladesh and the increased number of graduates produced each year require guidance when making decisions about the programs and universities that would best serve their learning and long-term career plans.

In an age of globalization, no nation can sufficiently evaluate the applicability or relevance of any factor or factors that indicate the employers' needs. In such a case, understanding the requirements of local and global employers is obviously not only a matter of concern for private universities but also for all institutions engaged with higher education. The outcomes and implications will be heading toward the interests of a broader educational community beyond that of private higher education providers.

Finally, the graduates must be adaptive to all the latest technologies and skillsets required by the job and the changing employment scenario. Such skills not only make them competent and valuable but also guarantee them sustainable career paths as expected.

\section{References}

Ahmed, R.I. and Crossman, J. (2014), "Significance of employability factors: Bangladesh perspectives", available at: www.researchgate.net/profile/Joanna_Crossman/publication/228597908_ Significance_of_Employability_Factors_Bangladesh_Perspectives/links/0c960531e5553b7748000 000/Significance-of-Employability-Factors-Bangladesh-Perspectives.pdf (accessed 22 November 2020).

Ambepitiya, K. (2016), "Employability of graduates of public and private management education institutes: a case study of two institutes in Sri Lanka", OUSL Journal, Vol. 11, pp. 113-134. 
Anderson, J.C. and Gerbing, D.W. (1984), "The effect of sampling error on convergence, improper solutions, and goodness-of-fit indices for maximum likelihood confirmatory factor analysis", Psychometrika, Vol. 49 No. 2, pp. 155-173.

Bentler, P.M. (1990), "Comparative fit indexes in structural models”, Psychological Bulletin, Vol. 107 No. 2, pp. 238-246.

Browne, M.W. and Cudeck, R. (1993), "Alternative ways of assessing model fit", Sage Focuses Editions, Vol. 154, pp. 126-136.

Cai, Y. (2013), 'Graduate employability: a conceptual framework for understanding employers' perceptions", Higher Education, Vol. 65 No. 4, pp. 457-469.

Chen, Y. (2017), "Graduate employability: the perspective of social network learning", EURASIA Journal of Mathematics Science and Technology Education, Vol. 13 No. 6, pp. 2567-2580.

Chisty, K.K.S., Uddin, G.M. and Ghosh, S.K. (2007), "The business graduate employability in Bangladesh: dilemma and expected skills by corporate world", BRAC University Journal, Vol. 4 No. 1, pp. 1-8.

Chowdhury, M.A.M. (2019), "Self-perceived employability of undergraduate students: Bangladesh perspective", Proceedings of the 2nd International Conference on Business and Management (ICBM 2019), 28 May- 2 June, BRAC University, Bangladesh.

Dotong, C.I. (2014), "School related factors in the development of graduates' competencies towards employability", Journal of Education and Literature, Vol. 2 No. 1, pp. 28-36.

Fenta, H., Asnakew, Z.S., Debele, P.K., Nigatu, S.T. and Muhaba, A.M. (2019), “Analysis of supply side factors influencing employability of new graduates: a tracer study of Bahir Dar university graduates", Journal of Teaching and Learning for Graduate Employability, Vol. 10 No. 2, pp. 67-85.

Field, A. (2000), Discovering Statistics Using SPSS for Windows, Sage publications, Thousand Oaks, London-New Delhi.

Finch, D.J., Hamilton, L.K., Baldwin, R. and Zehner, M. (2013), "An exploratory study of factors affecting undergraduate employability”, Education + Training, Vol. 55 No. 7, pp. 681-704.

Fitriyanto, M.N. and Pardjono, P. (2017), "Factors affecting the employability skills of vocational students majoring mechanical engineering", Jurnal Pendidikan Vokasi, Vol. 9 No. 2, pp. 195-197.

Gowsalya, G. and Kumar, M.A. (2015), "Employability skill: a literature review", International Journal of Advance Research in Computer Science and Management Studies, Vol. 3 No. 3, pp. 353-360.

Guilbert, L., Bernaud, J., Gouvernet, B. and Rossier, J. (2016), "Employability: review and research prospects", International Journal for Educational and Vocational Guidance, Vol. 16 No. 1, pp. 69-89.

Hair, J.F., Anderson, R.E., Tatham, R.L. and Black, W.C. (1998), Multivariate Data Analysis, 5th ed., Prentice Hall, Upper Saddle River, NJ.

Hair, J.F., Black, W.C. and Babin, B.J. (2010), Multivariate Data Analysis: A Global Perspective, Pearson Education, CA.

Helena, P.L. and Kena, H. (2019), "In the eyes of the beholder': the influence of academic performance and extracurricular activities on the perceived employability of Chinese business graduates", Asia Pacific Journal of Human Resources, Vol. 57 No. 4, pp. 503-527.

Hossain, M., Alam, M., Alamgir, M. and Salat, A. (2020), "Factors affecting business graduates' employability-empirical evidence using partial least squares (PLS)", Education + Training, Vol. 62 No. 3, pp. 292-310.

Hu, L.T. and Bentler, P.M. (1998), "Fit indices in covariance structure modeling: sensitivity to under parameterized model misspecification", Psychological Methods, Vol. 3 No. 4, pp. 424-453.

Jayasingha, D.G.M.S. and Suraweera, S.M.B.L. (2020), "An analysis of the factors affecting the graduates' employability in case of Rajarata university of Sri Lanka”, IRE Journals, Vol. 3 No. 12, pp. 10-24. 
Joreskog, K. and Sorbom, D. (1993), LISREL 8: Users' Reference Guide, Scientific Software International, IL.

Kalfa, S. and Taksa, L. (2015), "Cultural capital in business higher education: reconsidering the graduate attributes movement and the focus on employability", Studies in Higher Education, Vol. 40 No. 4, pp. 1-16.

Liyanage, P., Kumara, U. and Withanawasam, M. (2016), "Employability of the management graduates in Sri Lanka a case study", 11th Faculty of Management Studies and Commerce Research Symposium, 10 June-13 June, University of Sri Jayewardenepura, Sri Lanka.

McQuaid, R.W. and Lindsay, C. (2005), "The concept of employability”, Urban Studies, Vol. 42 No. 2, pp. 197-219.

MacKinnon, D.P. (2008), Research Designs: Quantitative, Qualitative, Neuropsychological and Biological, 5th ed., American Psychological Association, Washington, DC.

Mansour, B.E. and Dean, J.C. (2016), "Employability skills as perceived by employers and university faculty in the fields of human resource development (HRD) for entry level graduate jobs", Journal of Human Resource and Sustainability Studies, Vol. 4 No. 1, pp. 39-49.

Marsh, H.W. and Hocevar, D. (1985), "Application of confirmatory factor analysis to the study of selfconcept: first-and higher order factor models and their invariance across groups", Psychological Bulletin, Vol. 97 No. 3, pp. 562-582.

Nazron, M.A., Lim, B. and Nga, J.L.H. (2017), "Soft skills, attributes and graduate employability: a case in university Malaysia Sabah", Malaysian Journal of Business and Economics, Vol. 4 No. 2, pp. 65-76.

Neneh, B.N. (2019), "An empirical study of personality traits, job market appraisal and self-perceived employability in an uncertain market", Higher Education, Skills and Work-Based Learning, Vol. 10 No. 1, pp. 255-274.

Nunnally, J.C. and Bernstein, I.H. (1994), Psychometric Theory, 3rd ed., McGraw Hill, New York, NY.

Nusrat, M. and Sultana, N. (2019), "Soft skills for sustainable employment of business graduates of Bangladesh”, Higher Education, Skills and Work-Based Learning, Vol. 9 No. 3, pp. 264-278.

Paddi, K. (2014), "Perceptions of employability skills necessary to enhance human resource management graduates' prospects of securing a relevant place in the labor market", European Scientific Journal, Vol. 20, pp. 129-143.

Pinto, L.H. and Ramalheira, D.C. (2017), "Perceived employability of business graduates: the effect of academic performance and extracurricular activities", Journal of Vocational Behavior, Vol. 99, pp. 165-178.

Potgieter, I. and Coetzee, M. (2013), "Employability attributes and personality preferences of postgraduate business management students", SA Journal of Industrial Psychology, Vol. 39 No. 1, pp. 1-10.

Qureshi, A., Wall, H., Humphries, J. and Balani, A.B. (2016), "Can personality traits modulate student engagement with learning and their attitude to employability?", Learning and Individual Differences, Vol. 51, pp. 349-358.

Rad, H.F., Parsa, A. and Rajabi, E. (2020), "Employability of Iranian engineering graduates: influential factors, consequences and strategies", Journal of Teaching and Learning for Graduate Employability, Vol. 11 No. 1, pp. 110-130.

Rahman, N.H.A., Omar, H., Mustafa, T., Jusoh, Z. and Romaiha, N.R. (2016), "Graduate employability: what went wrong?", In Abdullah, M., Yahya, W., Ramli, N., Mohamed, S. and Ahmad, B. (Eds), Regional Conference on Science, Technology and Social Sciences (RCSTSS 2014), Springer, Singapore, available at: https://doi.org/10.1007/978-981-10-1458-1_30 (accessed 22 November 2020).

Rasul, M.S., Rauf, R.A.A., Mansor, A.N., Yasin, R.M. and Mahamud, Z. (2013), "Graduate employability for manufacturing industry", Procedia - Social and Behavioral Sciences, Vol. 102 No. 22, pp. 150-242. 
Reid, J. (2016), "Redefining 'employability' as something to be achieved: utilising Tronto's conceptual framework of care to refocus the debate", Higher Education, Skills and Work-Based Learning, Vol. 6 No. 1, pp. 55-68.

Shah, R.J. and Srivastava, N. (2014), "A study on factors affecting employability skills of management students", International Journal of Management and Development Studies, Vol. 3 No. 2, pp. 17-24.

Soon, J.J., Lee, A.S.H., Lim, H.E., Idris, I. and Eng, W.Y.K. (2019), "Cubicles or corner offices? Effects of academic performance on university graduates' employment likelihood and salary", Studies in Higher Education, Vol. 45 No. 6, pp. 1233-1248.

Sposito, V.A., Hand, M.L. and Skarpness, B. (1983), "On the efficiency of using the sample kurtosis in selecting optimal lpestimators", Communications in Statistics - Simulation and Computation, Vol. 12 No. 3, pp. 265-272.

Subbu, N.M. and Rajasekaran, V. (2018), "Employability skills: a review”, IUP Journal of Soft Skills, Vol. 12 No. 1, pp. 29-37.

Succi, C. and Canovi, M. (2020), "Soft skills to enhance graduate employability: comparing students and employers' perceptions", Studies in Higher Education, Vol. 45 No. 9, pp. 1834-1847.

Sumanasiri, E.G.T., Yajid, M.S.A. and Khatibi, A. (2015), "Review of literature on graduate employability", Journal of Studies in Education, Vol. 5 No. 3, pp. 75-88.

Teichler, U. (2009), "Higher education and the world of work: conceptual frameworks, comparative perspectives, empirical findings", Global Perspectives on Higher Education, Vol. 16, pp. 242-247.

Tholen, G. (2014), "Graduate employability and educational context: a comparison between Great Britain and The Netherlands", British Educational Research Journal, Vol. 40 No. 1, pp. 1-17.

Tomlinson, M. (2012), "Graduate employability: a review of conceptual and empirical themes", Higher Education Policy, Vol. 25 No. 4, pp. 407-431.

Weligamage, S. and Siengthai, S. (2003), "Employer needs and graduate skills: the gap between employer expectations and job expectations of Sri Lankan university graduates", Conference International Conference on Sri Lanka Studies, 21 May-25 May, Mathara, Sri Lanka.

Weligamage, S.S. (2009), "Graduates' employability skills: evidence from literature review”, Enhancing Employability through Quality Assurance - ASAIHL 2009, 27 June-30 June, University of Kelaniya, Sri Lanka.

Yamane, T. (1967), Elementary Sampling Theory, Prentice-Hall, Englewood Cliffs, NJ.

Yorke, M. and Knight, P. (2007), "Evidence-informed pedagogy and the enhancement of student employability", Teaching in Higher Education, Vol. 12 No. 2, pp. 157-170.

Yulia, S. and Yuzhuo, C. (2017), "Factors affecting the employability of international graduates", Working Paper No. UDC 331.5:378.141:376.68-057.87(045), School of Management, University of Tampere, Finland. 
Survey questionnaire

Segment-1 (Demographic information)

Please tick $(\sqrt{ })$ at the appropriate box

Segment-1

- Name of the participant:

- Sex (Please choose a category): $\square$ Male $\square$ Female

- Age level (Year): $\square$ 25-34 $\square 35-44 \quad \square 45$ or more

- Education level (Please choose a category): $\square$ Undergraduate $\square$ Graduate

Postgraduate or $\mathrm{PhD}$

-Nature of organization (Industry): $\square$ Manufacturing $\square$ Telecommunication $\square$ Bank \&

Insurance $\square$ Education $\square$ IT $\square$ Transport $\square$ Sipping $\square$ Postal Service $\square$ Print \&

Electronic Media $\square$ Food \& Beverage $\square$ Hotel \& Tourism

- Length of service: $\square 5$ or less $\square$ 6-10 $\square$ 11-15 $\square 16$ or more

\section{Segment-2}

This questionnaire has been prepared using 5 point Likert Scale to reveal the applicants' perception privacy, fairness and ethics regarding the use of social networking information in order to check job candidates' background. Score 1 represents strongly disagree, 2 represents disagree, 3 represents neutral, 4 represents agree and 5 represents strongly agree. Please tick $(\sqrt{ })$ at the appropriate box.

\begin{tabular}{|c|c|c|c|c|c|c|}
\hline \multicolumn{7}{|c|}{ Academic Performance (AC) } \\
\hline SI. & \multirow{2}{*}{ Items } & \multicolumn{5}{|c|}{ Scale } \\
\hline No. & & 1(SD) & 2(D) & $3(\mathrm{~N})$ & $4(A)$ & $5(\mathrm{SA})$ \\
\hline AP1 & $\begin{array}{l}\text { Academic performance is an indicator of candidate's } \\
\text { employability at my organization }\end{array}$ & & & & & \\
\hline AP2 & $\begin{array}{l}\text { My organization considers academic performance as an } \\
\text { important indicator of employability although it is not the } \\
\text { only one }\end{array}$ & & & & & \\
\hline$\overline{\text { AP3 }}$ & $\begin{array}{l}\text { The condition good academic performance can be } \\
\text { relaxed for exceptionally qualified job candidates }\end{array}$ & & & & & \\
\hline
\end{tabular}

Technical Skills (TS)

\begin{tabular}{|c|l|l|l|l|l|l}
\hline Sl. & \multicolumn{1}{c|}{ Items } & \multicolumn{3}{c}{ Scale } \\
\cline { 3 - 7 } No. & & 1(SD) & 2(I) & 3(N) & 4(A) & 5(SA) \\
\hline TS1 & $\begin{array}{l}\text { Technical skills are one of the mandatory competencies } \\
\text { for employability in my organization }\end{array}$ & & & & & \\
\hline TS2 & Candidates with sound technical skills are better sought & & & & & \\
\hline TS3 & $\begin{array}{l}\text { Candidates with technical skills are better equipped for } \\
\text { solving any challenges }\end{array}$ & & & & \\
\hline
\end{tabular}

Communication Skills (CS)

\begin{tabular}{|c|l|l|l|l|l|l}
\hline Sl. & \multicolumn{1}{c}{ Items } & \multicolumn{3}{c}{ Scalc } \\
\cline { 5 - 7 } No.
\end{tabular}

\begin{tabular}{|c|c|c|}
\hline \multicolumn{3}{|c|}{ Personality (PE) } \\
\hline Sl. & Items & Scale \\
\hline
\end{tabular}

(continued) 
Graduate

\begin{tabular}{|c|l|l|l|l|l|l|}
\hline No. & \multicolumn{1}{|l|}{} & & & \\
\hline PE1 & $\begin{array}{l}\text { I believe a candidate with strong personality have better } \\
\text { commitment to his/her job }\end{array}$ & & & & \\
\hline PE2 & Personality can be developed & & & & & \\
\hline PE3 & $\begin{array}{l}\text { A candidate with strong personality have the leadership } \\
\text { qualities }\end{array}$ & & & & & \\
\hline
\end{tabular}

Leadership \& Motivational Skills (LMS)
\begin{tabular}{|l|l|l|l|l|l|l|}
\hline SI. No. & \multicolumn{1}{|c|}{ Items } & \multicolumn{3}{|c|}{ Scale } \\
\cline { 5 - 7 } & LMS1 & Only a good leader can motivate his/her followers & $\mathbf{2 ( D )}$ & $\mathbf{3 ( N )}$ & $4(\mathbf{A})$ & $\mathbf{5}(\mathbf{S A})$ \\
\hline LMS2 & $\begin{array}{l}\text { We strongly seek the candidates with leadership and } \\
\text { motivational skills }\end{array}$ & & & & \\
\hline LMS3 & $\begin{array}{l}\text { My organization is one of the best places to develop } \\
\text { leadership \& motivational skills }\end{array}$ & & & & \\
\hline LMS4 & $\begin{array}{l}\text { My organization encourages its employees to develop } \\
\text { leadership \& motivational skills }\end{array}$ & & & & \\
\hline
\end{tabular}

Teamwork \& Problem Solving Skills (TPS)

\begin{tabular}{|c|c|c|c|c|c|c|}
\hline \multirow[t]{2}{*}{ Sl. No. } & \multirow[t]{2}{*}{ Items } & \multicolumn{5}{|c|}{ Scale } \\
\hline & & 1 (SD) & 2(D) & $3(\mathrm{~N})$ & $4(\mathrm{~A})$ & $5(\mathrm{SA})$ \\
\hline TPS1 & $\begin{array}{l}\text { Teamwork and problem solving are two very essential } \\
\text { skills to be hired }\end{array}$ & & & & & \\
\hline TPS2 & $\begin{array}{l}\text { We strongly seek the candidates with better teamwork } \\
\text { and problem solving capabilities }\end{array}$ & & & & & \\
\hline TPS3 & $\begin{array}{l}\text { Candidates and problem solving skills are tested through } \\
\text { brainstorming and real problem solving tests }\end{array}$ & & & & & \\
\hline
\end{tabular}

Overall Graduate Employability (EM)

\begin{tabular}{|l|l|l|l|l|l|l|}
\hline SI. No. & \multicolumn{1}{|c|}{ Items } & \multicolumn{1}{|c|}{ Scale } \\
\cline { 5 - 6 } OGE1 & $\begin{array}{l}\text { Only the best candidates are employed at my } \\
\text { organization }\end{array}$ & & & & & $\mathbf{1 ( S D )}$ \\
\hline OGE2 & $\begin{array}{l}\text { My organization provides a better chance to the fresh } \\
\text { graduates }\end{array}$ & & & & & \\
\hline OGE3 & $\begin{array}{l}\text { Before hiring, all the selected candidates go through } \\
\text { strict and detailed selection tests }\end{array}$ & & & & \\
\hline OGE4 & $\begin{array}{l}\text { The HRM professionals in my organization are expert to } \\
\text { employ the best candidates }\end{array}$ & & & & \\
\hline
\end{tabular}

Note: The information will be solely used for the purpose of above mentioned study and will be kept strictly confidential.

\section{Corresponding author}

Md Sajjad Hosain can be contacted at: sajjad_hosain@yahoo.com

For instructions on how to order reprints of this article, please visit our website: www.emeraldgrouppublishing.com/licensing/reprints.htm Or contact us for further details: permissions@emeraldinsight.com 